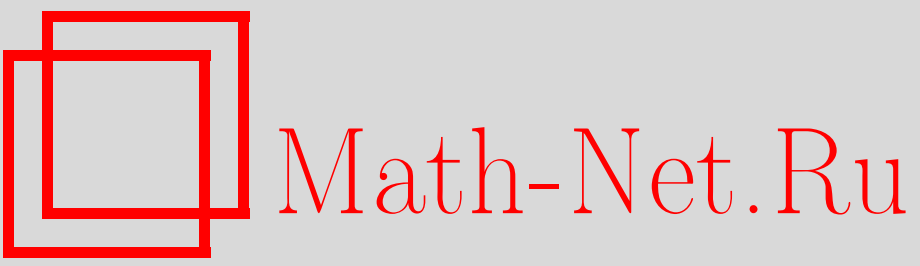

Ю. М. Брезанский, С. Г. Гиндикин, С. С. Кутателадзе, П. А. Кучмент, С. П. Новиков, Ю. Г. Решетняк, С. А. Скляднев, В. М. Тихомиров, Селим Григорьевич Крейн (некролог), УМH, 2000, том 55, выпуск 2, 125-126

DOI: https://doi.org/10.4213/rm270

Использование Общероссийского математического портала Math-Net.Ru подразумевает, что вы прочитали и согласны с пользовательским соглашением http: //www. mathnet.ru/rus/agreement

Параметры загрузки:

IP : 54.224 .187 .69

26 апреля 2023 г., 15:29:27 


\section{СЕЛИМ ГРИГОРЬЕВИЧ КРЕЙН}

16 августа 1999 года скончался доктор технических наук, профессор, Заслуженный деятель науки и техники Р $\Phi$ Селим Григорьевич Крейн. От нас ушел выдающийся ученый и замечательный человек.

Селим Григорьевич Крейн родился 15 июля 1917 года, в 1940 году закончил механико-математический факультет Киевского государственного университета. С 1940 по 1941 годы он обучался в аспирантуре под руководством Н. Н. Боголюбова.

В 1942 году Селим Григорьевич зашитил кандидатскую диссертацию, содержащую ставшую в дальнейшем классической теорему Крейна-Какутани. В годы войны Селим Григорьевич под руководством М. А. Лаврентьева участвует в разработке математической теории кумулятивных снарядов. Эти работы послужили основой его диссертации на соискание ученой степени доктора технических наук, которая была

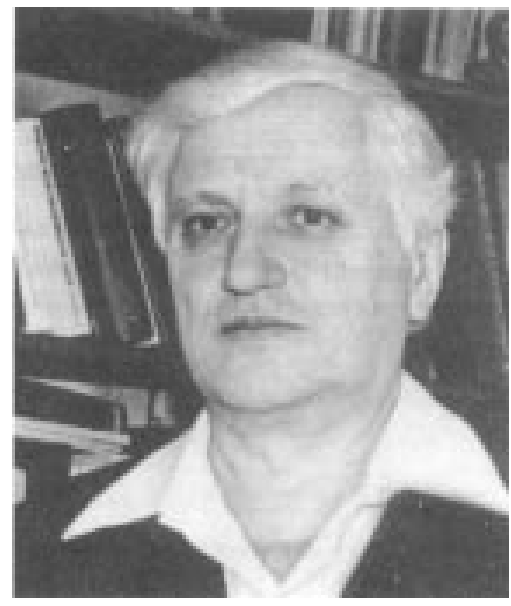
защищена в 1950 году в Академии артиллерийских наук.

В 1950-1951 годах Селим Григорьевич руководит отделом вьчислительной математики Института математики АН УССР.

В 1954 году Селим Григорьевич переезжает в Воронеж, где в полной мере расцвел его талант ученого, лектора и организатора. Он работает в Лесотехническом институте и на математическом факультете университета. Работает на совесть, на износ, имея одновременно до 10 аспирантов, читая несколько поточных лекций в год по основным дисциплинам и выполняя многочисленные обязанности заведуюшего кафедрой. Его годовая учебная нагрузка зачастую превышала 1000 часов.

Он любил свою работу, все студенты и коллеги любили его - это был по настоящему самый счастливый период жизни Селима Григорьевича.

Селимом Григорьевичем было опубликовано 170 статей, восемнадцать монографиий и один учебник. Поражает многообразие его научных интересов: совместно с Ю. Л. Далецким он вводит и исследует понятие двойного операторного интеграла; вместе с Ю. М. Березанским рассматривает важный класс банаховых алгебр - гиперкомплексные системы с континуальным базисом; вместе с И. А. Коренблюмом и Б. Я. Левиным применяет методы функционального анализа к изучению сингулярных интегралов. Важное место в научной деятельности Селима Григорьевича занимает теория интерполяции линейных операторов, одним из создателей которой он является. Разработанный им метод шкал банаховых пространств нашел важные применения не только в теории операторов, но и в теории граничных задач для дифференциальных уравнений, теории ортогональных рядов и других разделах анализа.

Селим Григорьевич одним из первых применил методы функционального к задачам гидродинамики. Им получены фундаментальные результаты в задаче о колебании вязкой несжимаемой 
жидкости в открытом сосуде. Задачи гидродинамики привели Селима Григорьевича к необходимости исследования дифференциальных уравнений с неограниченными операторами в банаховых пространствах. Им и его учениками разработан фактор-метод- абстрактный аналог разностного метода изучения устойчивости разностных схем.

В различных задачах математической физики встречаются переопределенные системы дифференциальных уравнений в частных производных. Селим Григорьевич совместно с учениками разработал метод ортогонального расширения таких систем, что позволило дать явное описание нетеровых краевых задач для таких важных систем, как системы уравнений векторного анализа, уравнения Максвелла, уравнения с операторами внешнего дифференцирования.

Селим Григорьевич был талантливым педагогом и блестящим лектором. Его лекции были тщательно подготовлены, всесторонне продуманы, интересны. Он всегда был окружен молодыми математиками, всегда был рад помочь им в решении математических и житейских проблем. Под его руководством было защищено 83 кандидатские диссертации, что поистине является научным подвигом! Девятнадцать его учеников стали докторами наук, а первые его ученики - Ю. М. Березанский и Ю. Л. Далецкий - были избраны действительными членами национальной Академии наук Украины.

Организованные Селимом Григорьевичем Воронежские зимние математические школы более тридцати лет пользуются широкой популярностью среди математиков.

Селим Григорьевич был выдающимся математиком, талантливым педагогом, кристально честным человеком. Мы всегда будем помнить Селима Григорьевича.

Ю. М. Березанский, С. Г. Гиндикин, С. С. Кутателадзе, П. А. Кучмент, С. П. Новиков, Ю.Г. Решетняк, Е. М. Семенов, С. А. Скляднев, В. М. Тихомиров 